
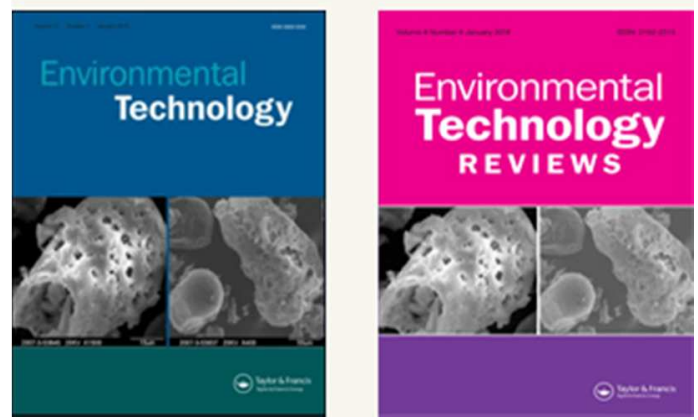

\title{
The effect of seasonal variations on floc morphology in activated sludge process
}

\begin{tabular}{|r|l|}
\hline Journal: & Environmental Technology \\
\hline Manuscript ID & Draft \\
\hline Manuscript Type: & Original Article \\
\hline Complete List of Authors: & $\begin{array}{l}\text { Koivuranta, Elisa; University of Oulu, Fibre and Particle Engineering } \\
\text { Research Unit } \\
\text { Suopajärvi, Terhi; University of Oulu, Fibre and Particle Engineering } \\
\text { Research Unit } \\
\text { Hattuniemi, Joni; Valmet } \\
\text { Stoor, Tuomas; University of Oulu, Fibre and Particle Engineering Research } \\
\text { Unit } \\
\text { Illikainen, Mirja; University of Oulu, Fibre and Particle Engineering } \\
\text { Research Unit }\end{array}$ \\
\hline Keywords: & $\begin{array}{l}\text { Floc formation, Filamentous bacteria, floc-forming bacteria, image analysis, } \\
\text { settling }\end{array}$ \\
\hline & \\
\hline
\end{tabular}

\section{SCHOLARONE"}

Manuscripts 


\title{
The effect of seasonal variations on floc morphology in activated sludge process
}

\author{
Koivuranta, Elisa ${ }^{\mathrm{a}, *}$; Suopajärvi Terhi ${ }^{\mathrm{a}}$; Hattuniemi, Joni ${ }^{\mathrm{b}}$; Stoor, Tuomas ${ }^{\mathrm{a}}$; \\ Illikainen, Mirja ${ }^{\mathrm{a}}$ \\ ${ }^{a}$ Fibre and Particle Engineering Research unit, Erkki Koiso-Kanttilan katu, PL 4300, \\ 90570 University of Oulu, Finland \\ ${ }^{b}$ Valmet, Kehräämöntie 3, 87400, Kajaani, Finland \\ *Corresponding author, Tel: +358405422794, e-mail address: elisa.koivuranta@oulu.fi
}




\section{The effect of seasonal variations on floc morphology in activated sludge process}

The effect of seasonal variations on floc formation in activated sludge process was studied in a municipal wastewater treatment plant in Finland nearly 16 months. Floc formation was measured with an online optical monitoring device, and results were correlated with the temperature of the upcoming wastewater and the purification efficiency of the activated sludge process. Results showed that floc formation has a clear, seasonal pattern, with flocs in summer being larger and rounder and having fewer filaments and small particles. In addition, purification efficiency increased in summer. The study correlated the results of image analysis with the composition (COD and SS content) and temperature of the wastewater before and after the activated sludge process. Results showed that the composition of upcoming wastewater has no clear correlation with floc morphological parameters. However, the wastewater temperature clearly correlated with floc formation. Results indicated that cold winter conditions enhanced the growth of filamentous bacteria in wastewater, decreasing purification efficiency. Furthermore, these results confirmed that floc formation has seasonal variations.

Keywords: Floc formation, filamentous bacteria, floc-forming bacteria, image analysis, settling

\section{Introduction}

The activated sludge process (ASP) is a common method of treating wastewater, since almost all wastewater contains biodegradable constituents that can be removed by micro-organisms. Micro-organisms consume organic matter from wastewater and produce flocs that can be removed by sedimentation [1]. Activated sludge plants operate under constantly changing conditions, including seasonal changes in temperature, wastewater composition and flow rate [2], and because of the biological nature of the process, ASP is highly sensitive to these variations [3].

Activated sludge consists mainly of biological flocs; thus, the balance of the bacteria population particularly affects floc formation $[4,5]$. The competition between 
two main bacteria types, floc-forming and filamentous bacteria, is affected by many factors, including variations in influent temperature, composition and flow rate [6]. For example, wastewater temperature influences biochemical reactions and oxygen transfer rates [2], thereby enabling various bacteria species to succeed. In general, filamentous bacteria are slow-growing compared to floc-forming bacteria [7]. The most common factors promoting the growth of filamentous bacteria are limitations in substrate (carbon, nitrogen and oxygen) and phosphorous and low concentrations of dissolved oxygen in the ASP $[6,8-11]$. In addition, low temperatures enhance the growth of filamentous bacteria [12]. The imbalance between floc-forming and filamentous bacteria affects floc structure and can lead to settling problems in the ASP [5, 7]. Some studies have found seasonal variations in ASP, especially in sludge settleability, which is measured mainly as sludge volume index (SVI). For example, Graveleau et al. [13], Krult et al. [14] and Oerther et al. [10] found that average SVI values were higher in winter than in summer. In contrast, Wilén et al. [15] and Liwarska-Bizukojc [16] found no seasonal variations in settleability properties when measured as stirred SVI and SVI at municipal wastewater treatment plants (WWTPs). However, Wilén et al. [15] found seasonal variations measured as effluent suspended solids (SS) and chemical oxygen demand (COD) concentrations and that in summer, purification generally improved. Thus, the differences among studies might be because SVI is a non-specific measurement and its normal range of values varies in every WWTP $[8,17]$. In addition, SVI is not a straightforward measurement, as various flocculation abnormalities affect SVI measurement in various ways [18, 19]. In contrast, SS in the effluent is used to quantify SS escape into waterways, and therefore is a better indicator of purification efficiency. 
Although there have been some studies in this field, none have addressed how seasonal variations in wastewater temperature affect floc formation in an actual ASP and thus affect purification level. Therefore, the aim of this study was to examine how wastewater temperature affects floc formation in a municipal WWTP to better understand how seasonal variations influence the ASP. The experiments lasted for nearly 16 months and analysed floc formation using a tube-flow imaging system introduced by Koivuranta et al. [20]. The system was used online and provided a significant amount of data on floc formation, including floc size and shape and filament number.

\section{Materials and methods}

\section{Description of the wastewater treatment plant}

The WWTP studied is located in southern Finland and uses an ASP method featuring simultaneous precipitation. Thus, wastewater treatment at the plant uses mechanical, biological and chemical processes. Phosphorous is removed by chemical precipitation with ferrous sulphate dosing at the beginning of grit removal and after aeration. Fig. 1 presents a simplified schematic illustration of the municipal WWTP, which has nine parallel ASP lines, each with its own sludge-handling system. From the secondary settling area, the wastewater is led to biological filtration to enhance denitrification. The wastewater treated in the plant comes primarily from domestic sources, and the average amount of water treated is $280,000 \mathrm{~m} 3 /$ day. The WWTP's legal discharge limits for $\mathrm{COD}$ are $<75 \mathrm{mg} / \mathrm{L}$ and for $\mathrm{SS},<15 \mathrm{mg} / \mathrm{L}$.

\section{Floc imaging system}

A detailed description of the floc imaging system used is presented in Koivuranta et al. 
[20]. The online optical monitoring device consists of a sample-handling unit, an imaging unit and a control PC and electronics unit. The imaging unit is equipped with an industrial charge-coupled device (CCD) camera, an LED light source and a flowthrough cuvette. The camera's resolution is $1392 \times 1040$ pixels, and the physical image size is $4.94 \mathrm{~mm} \times 3.96 \mathrm{~mm}$, resulting in spatial resolution of $3.55 \mu \mathrm{m}$. The sample is pumped from the wastewater process into a container, where the sample is diluted with tap water and pumped into the cuvette of the imaging unit. During the present study, videos of the samples were saved approximately four times a day. A single video contains about 1000 images, and an image contains an average of 200 flocs.

\section{Image analysis}

The automated image analysis programme used was presented by Koivuranta et al. [21]. This programme calculates the various size and shape parameters of each particle in each image. In the current study, the shape parameter (roundness) was calculated for the activated sludge flocs with area $>100 \mu \mathrm{m} 2$. In addition, the study calculated the equivalent diameter of the flocs and the proportion of small particles (defined as having an equivalent diameter of from $3.6-25 \mu \mathrm{m}$ ) relative to all particles. To quantify the filamentous bacteria, the total filament length per total floc area ratio was calculated. The mathematical formula for roundness was [22]:

$$
R O=\frac{4 \times \text { area }}{\pi \times \text { length }^{2}}
$$

\section{Offline process monitoring}

The ASP was monitored twice weekly for various quality parameters, including COD (SFS 50504:1988) and SS (SFS-EN 872-2005) contents. These parameters were measured by collecting grab samples from each line hourly. In addition, the temperature 
of treated wastewater was measured online daily, except the period when it was out of order.

\section{Statistical analysis}

Univariate linear correlation analyses were performed between the morphological parameters of flocs and the wastewater temperature and the composition of wastewater before and after biological treatment. Pearson's product-momentum correlation coefficient (rp) was used to linearly estimate strength and direction between two parameters. Correlations were considered statistically significant at a $95 \%$ confidence interval (CI) $(\mathrm{p}>0.05)$.

\section{Results}

\section{The composition and temperature of the wastewater and biologically purified water}

The study measured the composition of the wastewater in terms of SS and COD contents after mechanical (effluent from primary sedimentation) and biological (effluent from secondary sedimentation) treatment (Fig. 2a). After mechanical treatment, the COD of the wastewater varied from $200-400 \mathrm{mg} / \mathrm{L}$, and the SS varied from 75-225 $\mathrm{mg} / \mathrm{L}$. No significant seasonal variation was found in the composition of upcoming wastewater.

As indicated by the SS content in effluent after secondary sedimentation, biological treatment yielded various purification levels during the trial (Fig. 2b), including good, at below $10 \mathrm{mg} / \mathrm{L}$ (June-December) and poor, at more than $20 \mathrm{mg} / \mathrm{L}$ (March-April). Otherwise, the ASP operated normally, with purification levels of from 10-20 mg/L. After biological treatment, the COD content remained more stable, with slightly larger values in the beginning of the trial. 
During the trial, wastewater temperature varied significantly (Fig. 2c), from about $10^{\circ} \mathrm{C}$ at the coldest point to more than $20^{\circ} \mathrm{C}$ at the warmest.

\section{The effect of wastewater temperature on floc formation}

Fig. 3 presents the morphological parameters of flocs and wastewater temperature.

There was a clear, seasonal pattern in both temperature and morphological parameters, with larger flocs (Fig. 3a) and rounder flocs (Fig. 3b) and fewer filaments (Fig. 3c) and fewer small particles (Fig. 3d) when the wastewater temperatures were warmer.

\section{The effect of the floc morphological parameters to the purification results.}

Fig. 4 presents floc morphology and SS content in effluent after secondary sedimentation and highlights the effect of floc morphology on purification efficiency. These results revealed that the greatest purification efficiency was achieved with large (Fig. 4a) and round (Fig. 4b) flocs and when there were fewer filaments (Fig. 4c) and fewer small particles (Fig. 4d).

\section{Statistical analysis}

To facilitate the statistical analysis, the results of image analysis were paired with the wastewater temperature and composition before and after biological treatment. The results of statistical analysis were calculated using Pearson's correlation and are summarized in Table 1.

The correlation analysis showed that the roundness, filament length/floc area and proportion of small particles had clear correlations with wastewater temperature, indicating that in warm water, flocs are rounder and there are fewer filaments and small particles. In addition, the composition of mechanically treated water had no linear correlation with the morphological parameters of flocs. However, the roundness, 
number of filaments and proportion of small particles correlated with the SS content after biological treatment.

\section{Discussion}

The effluent clarity (Fig. 2b) showed that the WWTP had varying purification levels during the trial and that the purification was most efficient during late summer and early autumn and least efficient during winter and spring. In addition, floc formation had a clear, seasonal pattern, most likely due to seasonal variations rather than upcoming wastewater composition. Results showed that upcoming wastewater composition (Fig. 2a) did not vary significantly during the trial and that wastewater temperature clearly affected the floc morphology, as presented in Fig. 3. Furthermore, the results of statistical analysis confirmed this, as presented in Table 1.

Based on the results of image analysis, cold wastewater promoted the growth of filamentous bacteria, which can be seen by the increased number of filaments (Fig. 3c) and irregularly shaped flocs (Fig. 3b). In addition, the flocs were smaller (Fig. 3a) and there were more small particles (Fig. 3d) when the wastewater temperature was colder. Based on the floc breakage study by Koivuranta et al. [23], the increased number of filaments can be linked to large-scale fragmentation, which could mean that filamentous overgrowth cause flocs to break up, causing small particles and smaller floc size. These results are similar to those of Wilen et al. [15] who found that, in general, flocs had weaker structure during winter, causing higher concentrations of SS in the effluent. Jones et al. [1] found that both filament content and biomass density played an important role in seasonal variations in activated sludge settleability. They found generally lower density values in cold weather [1]. In addition, da Motta et al. [4] found that flocs were slightly bigger during summer, and Mielczarek et al. [24] found seasonal variations in flocs, with irregular flocs during winter and more-compact flocs during the 
rest of the year, which is similar to the results of the present study. Furthermore, Mielczarek et al. [24] concluded that the main controlling factors affecting filamentous bacteria are most likely to be the substrate composition of the influent, and LiwarskaBizukojck et al. [16] reported that the sludge-loading rate and oxido-reductive conditions have more significant effects on floc size than temperature, both of which differs from the results of the present study.

In addition, previous studies $[13,24,25]$ have sought to identify seasonal patterns in micro-organism populations. Mielczarek et al. [24] found that temporal changes in species composition and abundance in individual WWTPs were low over long-term observation. However, they found that a Microthirx bacterium, which is one of the most common filamentous bacteria, was most abundant in winter, although they did not observe a clear, seasonal variation in the filaments [24]. Graveleau et al. [13] found no significant seasonal differences in terms of micro-organism population distribution, although they found a seasonal pattern in SVI values. However, Flowers et al. [25] found that temperature was the environmental variable that best correlated with changes in bacteria species and that bacteria species cycled through a predictable, seasonal pattern yearly, which confirms the results of the present study.

Oerther et al. [10] suggested that higher temperatures may enhance the growth of filamentous bacteria involved in initiating foaming. In their case, the SVI values in the aeration basin were low during initiation of filamentous foaming, meaning that the foaming event coincided with well settling biomass and was not associated with sludge bulking [10]. In addition, in the WWTP studied by de los Reyes et al. [26], there was seasonal foaming, generally from June-September. These results verified that wastewater temperature clearly affects the bacteria balance of activated sludge, although the problem can differ between warm climates and cold ones. 
The results of the present study confirmed that floc formation has predictable, seasonal patterns. The present study found that floc morphology had effect on wastewater purification efficiency, with the best purification results achieved with when larger (Fig. 4a) and rounder (Fig. 4b) flocs and fewer filaments (Fig. 4c) and small particles (Fig. 4d) were present. Therefore, wastewater temperature is an environmental parameter that needs to be taken into account in controlling ASP. Some remedial actions, including adding nutrients or oxygen or increasing the sludge-wasting rate, are needed to promote the growth of floc-forming bacteria during cold months. In addition, the imaging method used in the present study has possibility to be as a control system, as its feedback on floc formation is much more rapid than that provided by traditional measurements, including microscopic analysis (which is time-consuming and often subjective), SVI (which is a good indicator only in the case of filamentous bulking) or SS in the effluent (which reveals inefficient purification only after it has occurred).

\section{Conclusions}

The present study monitored seasonal variations in floc formation in the ASP in a municipal WWTP for nearly 16 months. Floc formation was measured with an online optical monitoring device, and results were correlated with upcoming wastewater temperature and ASP purification efficiency. Results showed that floc formation has clear, seasonal patterns, with flocs being larger and rounder and having fewer filaments and small particles in summer, which caused improved purification efficiency in summer. Unlike wastewater temperature, upcoming wastewater composition showed no clear, seasonal variations or any correlation with floc morphological parameters.

Therefore, results of the present study indicated that cold wastewater in winter enhanced the growth of filamentous bacteria, which decreased purification efficiency. 
Acknowledgements

This research was carried out as part of the Measurement, Monitoring and Environmental Efficiency Assessment (MMEA) research programme of CLEEN Ltd. - Cluster for Energy and Environment. The authors would also like to acknowledge Tekes (the Finnish Funding Agency for Technology) for financial support and Valmet for providing the floc-imaging equipment.

Reference list

[1] Jones PA, Schuler AJ. Seasonal variability of biomass density and activated sludge settleability in full-scale wastewater treatment systems. Chem. Eng. J. $2010 ; 164 ; 16-22$.

[2] Guo J, Fu X, Andrés Baquero G, Sobhani R, Nolasco DA, Rosso D. Trade-off between carbon emission and effluent quality of activated sludge processes under seasonal variations of wastewater temperature and mean cell retention time. Sci. Total Environ. 2016;547:331-344.

[3] Mesquita DP, Dias O, Amaral AL, Ferreira EC. Monitoring of activated sludge settling ability through image analysis: validation on full-scale wastewater treatment plants. Bioprocess Biosyst. Eng. 2009;32:361-367.

[4] Motta M, Pons M-N, Roche N, Vivier H. Characterisation of activated sludge by automated image analysis. Biochem. Eng. J. 2001;9:165-173.

[5] Mesquita DP, Dias O, Elias RAV, Amaral AL, Ferreira EC. Dilution and Magnification Effects on Image Analysis Applications in Activated Sludge Characterization. Microsc. Microanal. 2010;16: 561-568.

[6] Motta M, Pons M-N, Roche N. Monitoring filamentous bulking in activated sludge systems fed by synthetic or municipal wastewater. Bioprocess Biosyst. Eng. 2003;25:387-393.

[7] Turtin I, Vatansever A, Sanin FD. Phosphorus Defficiency and Sludge Bulking. Environ. Technol. 2006;27:613-621.

[8] Brault J-., Whalen P, Stuart P. Early warning signs of bulking in an activated sludge system through interpretation of ATP data in a systems analysis context. Environ. Technol. 2011;32:1649-1660.

[9] Contreras EM, Giannuzzi L, Zaritzky NE. Use of image analysis in the study of competition between filamentous and non-filamentous bacteria. Water Res. 2004;38:2621-2630. 
[10] Oerther DB, Reyes FL, Reyes MF, Raskin L. Quantifying filamentous microorganisms in activated sludge before, during, and after an incident of foaming by oligonucleotide probe hybridizations and antibody staining. Water Res. 2001;35:3325-3336.

[11] Wágner DS, Ramin E, Szabo P, Dechesne A, Plósz BG. Microthrix parvicella abundance associates with activated sludge settling velocity and rheology Quantifying and modelling filamentous bulking. Water Res. 2015;78:121-132.

[12] Knoop S, Kunst S. Influence of temperature and sludge loading on activated sludge settling, especially on. Water Sci. Technol. 1998;37:27-35.

[13] Graveleau L, Cotteux E, Duchène P. Bulking and Foaming in France: The 19992001 Survey. Acta Hydrochim. Hydrobiol. 2005;33:223-231.

[14] Kruit J, Hulsbeek J, Visser A. Bulking sludge solved?! Water Sci. Technol. J. Int. Assoc. Water Pollut. Res. 2002;46: 457-464.

[15] Wilén B-M, Lumley D, Mattsson A, Mino T. Relationship between floc composition and flocculation and settling properties studied at a full scale activated sludge plant. Water Res. 2008;42: 4404-4418.

[16] Liwarska-Bizukojc E, Klepacz-Smółka ., Andrzejczak O. Variations of morphology of activated sludge flocs studied at full-scale wastewater treatment plants. Environ. Technol. 2015;36:1123-1131.

[17] Jin B, Wilén B-M, Lant P. A comprehensive insight into floc characteristics and their impact on compressibility and settleability of activated sludge. Chem. Eng. J. 2003;95;221-234.

[18] Amaral A., Mesquita DP, Ferreira, EC, 2013. Automatic identification of activated sludge disturbances and assessment of operational parameters. Chemosphere 2013;91:705-710.

[19] Mesquita DP, Amaral AL, Ferreira EC. Identifying different types of bulking in an activated sludge system through quantitative image analysis. Chemosphere 2011;85:643-652.

[20] Koivuranta E, Stoor T, Hattuniemi J, Niinimäki J. On-line optical monitoring of activated sludge floc morphology. J. Water Process Eng. 2015;5:28-34.

[21] Koivuranta E, Keskitalo J, Haapala A, Stoor T, Sarén M, Niinimäki J. Optical monitoring of activated sludge flocs in bulking and non-bulking conditions. Environ. Technol. 2013;34: 679-686. 
[22] Russ JC. Computer-assisted microscopy: the measurement and analysis of images. 1990. Plenum Press, New York.

[23] Koivuranta E, Suopajärvi T, Stoor T, Hattuniemi J, Niinimäki J. Use of optical monitoring to assess the breakage of activated sludge flocs. Particulate Science and Technol. 2015;33:412-417.

[24] Mielczarek AT, Kragelund C, Eriksen PS, Nielsen PH. Population dynamics of filamentous bacteria in Danish wastewater treatment plants with nutrient removal. Water Res. 2012;46:3781-3795.

[25] Flowers JJ, Cadkin TA, McMahon KD. Seasonal bacterial community dynamics in a full-scale enhanced biological phosphorus removal plant. Water Res., Microbial ecology of drinking water and wastewater treatment. 2013;47:70197031.

[26] Reyes FL, Raskin L. Role of filamentous microorganisms in activated sludge foaming: relationship of mycolata levels to foaming initiation and stability. Water Res., Modern Scientific Tools in Bioprocessing. 2002;36:445-459. 
Table 1. Pearson's correlation coefficient values for the linear correlation between the image analysis results and the wastewater temperature and composition before and after biological treatment.

Figure 1. A simplified schematic of the municipal WWTP.

Figure 2. SS and COD contents in wastewater a) after mechanical, and b) after biological treatment and c) wastewater temperatures.

Figure 3. The effect of water temperature on a) floc size, b) floc shape, c) filament length/floc area and d) amount of small particles.

Figure 4. The variations in a) equivalent diameter of flocs, b) roundness, c) filament length/floc area and d) proportion of small particles. 
1

2

\begin{tabular}{lccccc}
\hline & $\begin{array}{c}\text { Water } \\
\text { temperature }\end{array}$ & $\begin{array}{c}\text { COD after } \\
\text { mechanical } \\
\text { treatment }\end{array}$ & $\begin{array}{c}\text { SS after } \\
\text { mechanical } \\
\text { treatment }\end{array}$ & $\begin{array}{c}\text { COD after } \\
\text { biological } \\
\text { treatment }\end{array}$ & $\begin{array}{c}\text { SS after } \\
\text { biological } \\
\text { treatment }\end{array}$ \\
\hline Equivalent diameter & 0.25 & -0.11 & 0.01 & -0.14 & -0.13 \\
Roundness & 0.80 & -0.08 & -0.01 & -0.37 & -0.63 \\
Filament length/floc area & -0.67 & 0.02 & -0.10 & 0.19 & 0.51 \\
Proportion of small particles & -0.72 & 0.05 & -0.06 & 0.40 & 0.59
\end{tabular}




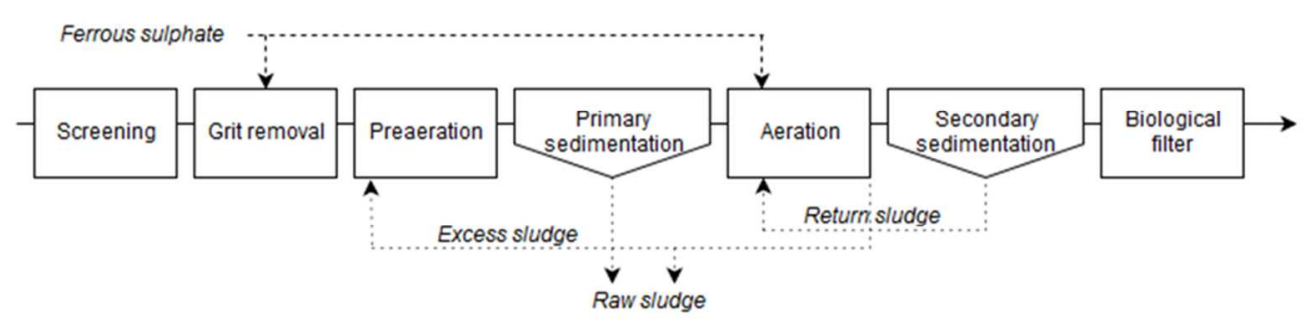

Figure 1. A simplified schematic of the municipal WWTP. 
Figure 2a. SS and COD contents in wastewater a) after mechanical, and b) after biological treatment and c) wastewater temperatures.

$208 \times 159 m m(300 \times 300$ DPI $)$ 


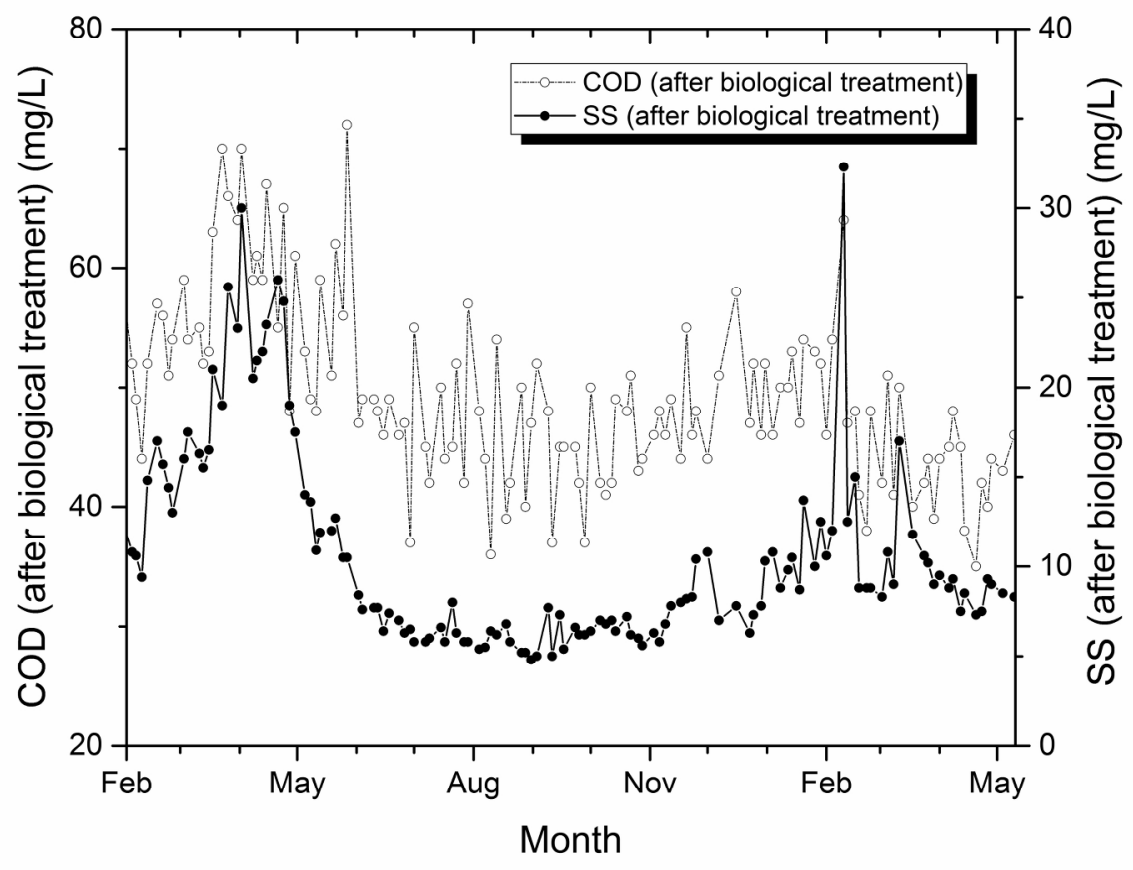

Figure 2b. SS and COD contents in wastewater a) after mechanical, and b) after biological treatment and c) wastewater temperatures.

$208 \times 159 \mathrm{~mm}(300 \times 300 \mathrm{DPI})$ 
Figure 2c. SS and COD contents in wastewater a) after mechanical, and b) after biological treatment and c) wastewater temperatures.

$208 \times 159 \mathrm{~mm}$ ( $300 \times 300$ DPI) 


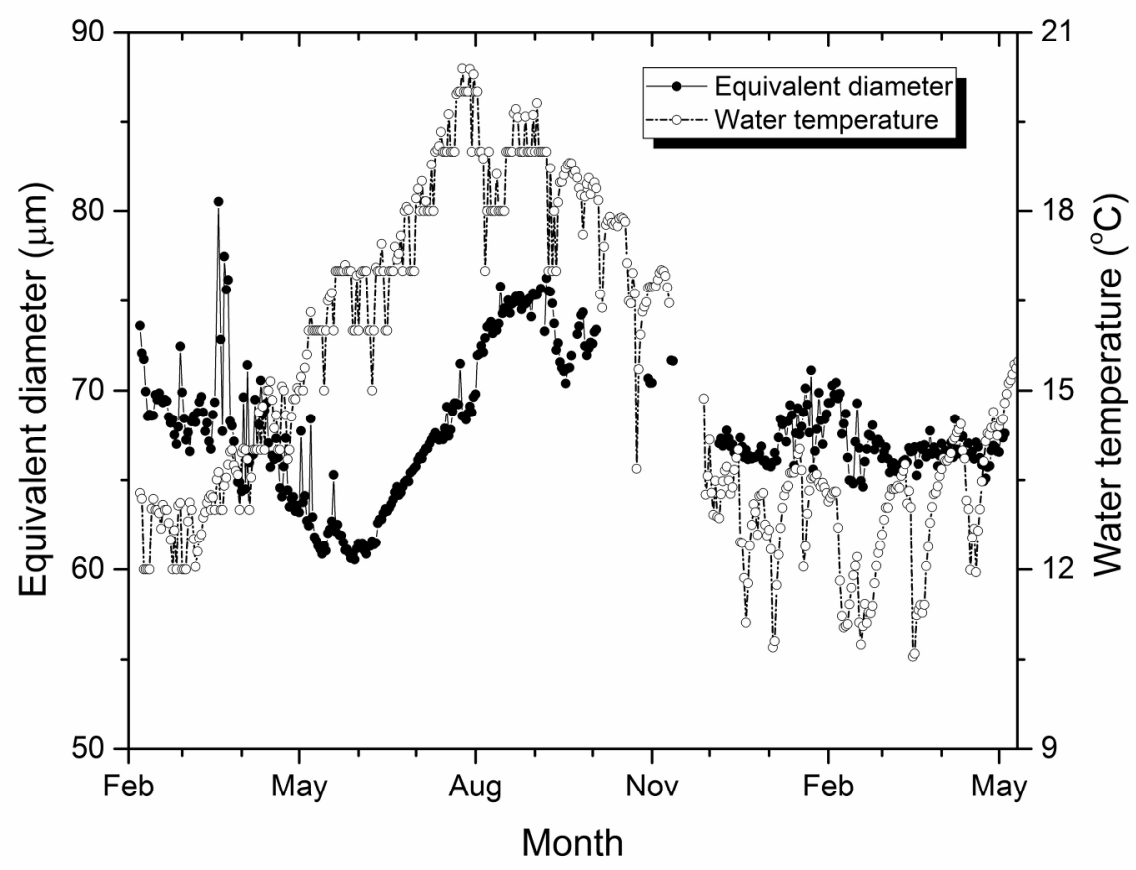

Figure 3a. The effect of water temperature on a) floc size, b) floc shape, c) filament length/floc area and d) amount of small particles.

$208 \times 159 \mathrm{~mm}(300 \times 300$ DPI $)$ 
Figure $3 b$. The effect of water temperature on a) floc size, b) floc shape, c) filament length/floc area and d) amount of small particles.

$208 \times 159 \mathrm{~mm}(300 \times 300$ DPI $)$ 


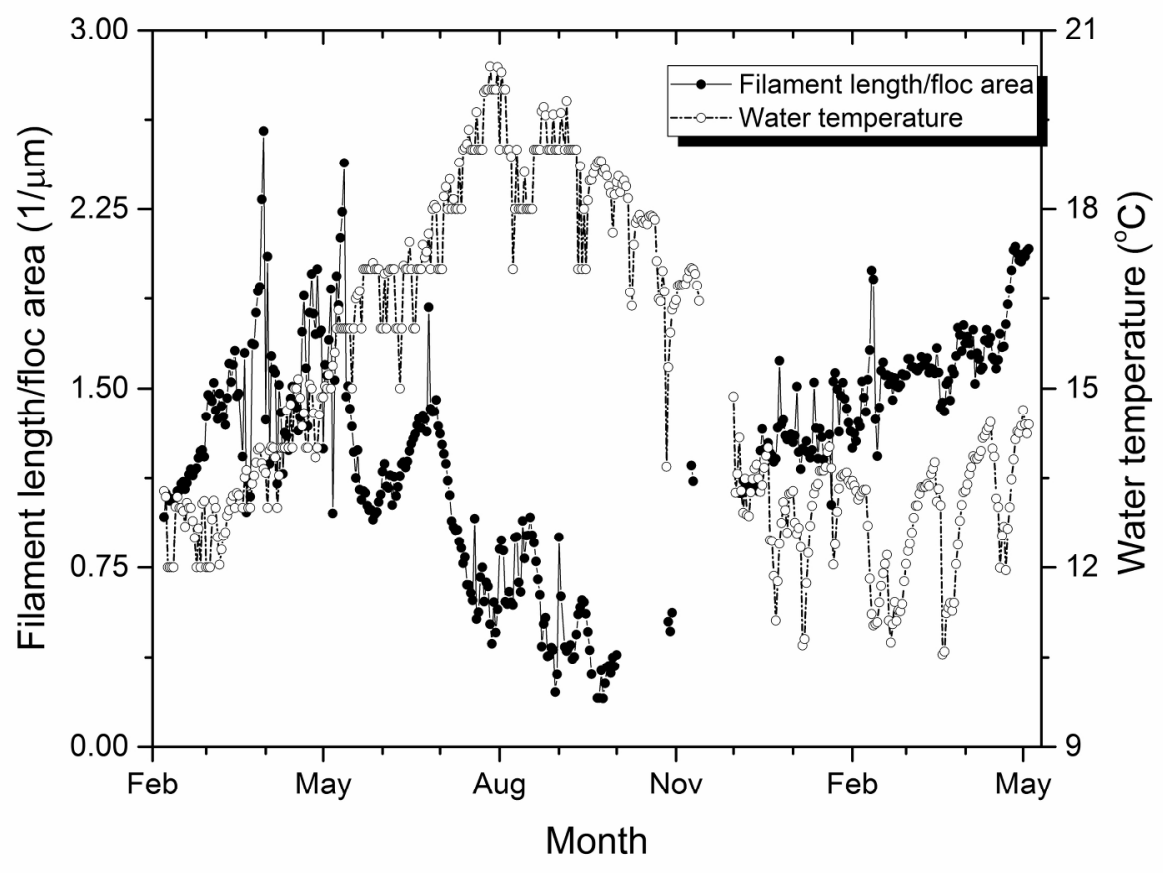

Figure 3c. The effect of water temperature on a) floc size, b) floc shape, c) filament length/floc area and d) amount of small particles.

$208 \times 159 \mathrm{~mm}(300 \times 300$ DPI $)$ 
Figure $3 d$. The effect of water temperature on a) floc size, b) floc shape, c) filament length/floc area and d) amount of small particles.

$208 \times 159 \mathrm{~mm}(300 \times 300$ DPI $)$ 
Figure $4 a$. The variations in a) equivalent diameter of flocs, b) roundness, c) filament length/floc area and d) proportion of small particles.

$208 \times 159 \mathrm{~mm}(300 \times 300$ DPI $)$ 
Figure 4b. The variations in a) equivalent diameter of flocs, b) roundness, c) filament length/floc area and d) proportion of small particles.

$208 \times 159 \mathrm{~mm}(300 \times 300$ DPI $)$ 


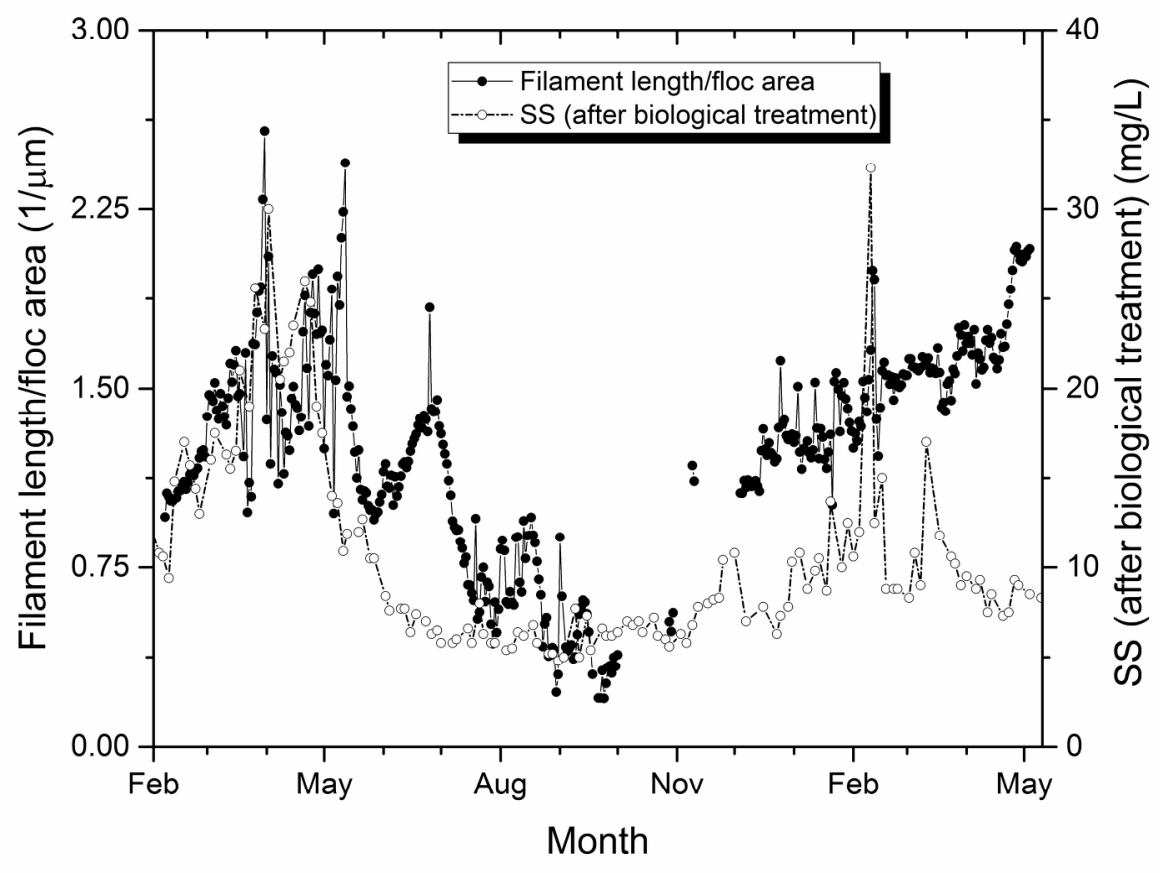

Figure 4c. The variations in a) equivalent diameter of flocs, b) roundness, c) filament length/floc area and d) proportion of small particles.

$208 \times 159 \mathrm{~mm}(300 \times 300 \mathrm{DPI})$ 
Figure 4d. The variations in a) equivalent diameter of flocs, b) roundness, c) filament length/floc area and d) proportion of small particles.

$208 \times 159 \mathrm{~mm}(300 \times 300$ DPI $)$ 